\title{
THE TENTH MALAYSIA PLAN: TRANSFORMATION TOWARDS A HIGH INCOME ADVANCED ECONOMY*
}

\author{
NOOR AZLAN GHAZALI \\ Head of Economic and Finance Cluster \\ National Professorial Council
}

\begin{abstract}
First of all, thanks for giving me the opportunity to share some of my views despite coming back just recently. Before I move ahead, I would like to just quickly give some quick overview of something very relevant with what we are going to discuss today because the 10th Malaysia Plan is unique in a couple of ways. First of all, in terms of the preparations for the plan. This time the 10th Malaysia Plan was prepared ahead of time, earlier than the schedule. It was not as usual because it was tabled last year. Basically, it was for implementation purposes as it was starting in 2011. And there are a couple of other changes in terms of how the government plans, in the 10th Malaysia Plan, to disburse the funds for development.
\end{abstract}

Basically, in my presentation today, I have four areas that I want to discuss. All the views that I am giving today are all my personal views. Some of them were accumulated while I was serving the Economic Planning Unit (EPU) as well as over the couple of years I was involved in a couple of other arenas of economic planning. My other views were accumulated through my personal reading. While I was in Harvard, one of the things that we did was doing a review. We looked at our own work as well as other people's work, as we sat on the floor, to see how things were being done to make our recommendations.

Let me just very quickly give a few glimpses of where we are. One of the glimpses is the growth momentum which I think underlies the 10th Malaysia Plan. Unfortunately after more than 15 years, or two thirds of the journey to Vision 2020, a lot of people have forgotten the major components of this vision. Very recently we had Yang Berbahagia Tun Dr. Mahathir Mohamad with us in the Majlis Profesor Negara during

\footnotetext{
* This paper was presented as a Keynote Address at the National Conference on the $10^{\text {th }}$ Malaysia Plan: Transformation Towards a High Income Advanced Economy on July 18, 2011, organized by the UUM Press in collaboration with the IJMS Editorial Board and the Malaysian Institute of Economic Research (MIER).
} 
the Kongres Profesor Negara. In this event, I think he made it very clear that Vision 2020 is not just about achieving qualitative targets but beyond that. If we read his speech very carefully - which he delivered back in 1991 - basically he also mentioned that it has to be the Malaysian way. So, while a lot of discussions on the $10^{\text {th }}$ Malaysia Plan or the Economic Transformation Programme (ETP) and so on are looking at the qualitative target, the nine so-called components, that is the soft components of Vision 2020, have also to be worked out and be monitored. I am yet to know who are actually in charge of these, who are addressing these and who are measuring these, and where we are at the moment.

Now, if we look at Malaysia overall, the flags basically show the downturn of the Malaysian economy, but between the second and the third flags, you see that the Malaysian economy, that is the red line which diverges from the soft line which is the world's economic performance, is the period of the Asean miracle. It is a miracle because a country like Malaysia normally will closely be associated with the world performance; any ups and downs. If we look at all the flags, the downturn are basically very much triggered by external factors; so for an economist it is not too difficult to predict the Malaysian economy.

Now, there is a lot of discussion pointing towards the slowing of the momentum of the Malaysian economy. It is very critical that we also recognize some of the successes that Malaysia has achieved. Whenever you mention Malaysia, everyone wants to know its success story. Look at this pattern of growth. Basically I look through all the world economic performance in terms of GNI per capital.

If we look at those who started at the same beginning point with Malaysia, we see that most of the countries are lower than us. If we compare their performances over the years, over the past 30 years or so, we can see that the thin background on the upper side. And then, we again start a new battle in the 1980's. You see, the list of the country has changed. Some of the countries in the first chart, until today, still remain a very problematic and very low economy growth. Some of them are so much excited when we talk about poverty but in the $80^{\prime}$ s, Malaysia remains on the top. If you compare that to the pace, on the average, we are doing very well. That is why when we discuss Malaysia abroad, people want to learn from us. How we do this? What is the magic behind this? The country that used to have more than $50 \%$ poverty in the 70 's suddenly drops all the way to 3.7 or something along that line. So, if you were to check with Africa, Malaysia is astonishing, basically this is remarkable, please come 
and share with us. That's why I mean over the years, probably one of the main assets that we tend to ignore is that we learn to get out of poverty.

And today more than a third of the world's economy is still suffering from that and that is actually something that we should be able to share with them. Nevertheless there are extraordinary cases. If you bring in a country like South Korea, you see that in South Korea the top line is really so different from other countries. But I call this as an extraordinary case, an extraordinary path, because on average, the class down there, is what reflects the average. But there are a couple of countries that somehow perform well beyond their peers. Now this is basically the challenge for us, Vision 2020. So when we count Vision 2020, we have to understand that what we want to achieve is that extraordinary path. So, if we want to remain and do as what we have been doing before, it will never take us towards that extraordinary path. That's why if you see over the years, Yang Berbahagia Tan Sri KSN for example, always mentioned that business is not as usual. This is not about change; this is not merely about growth but this is about transformational efforts. So this conference is very timely because it calls for transformational things. So I will discuss a bit more about transformations.

If we see for example, Korea used to be behind us. In fact in 1980, they were slightly behind us. But, as we moved into 2009, for example, it has more than doubled. But again remember Vision 2020, the 10th Malaysia Plan is about achieving the "extraordinary path". It is not an average path because on the average we have done quite ok. This is something that we have projected. This is where Malaysia is well this is not something confidential, because these are published materials. I remember that when we were about to put this there were change in the circular for the call to all the ministries to start working on the $10^{\text {th }}$ Malaysia Plan, there were some internal debates about whether we should put this in or not. I personally believed that at that time, it had to be there because it was a wake up call. Only before the crisis of 1998, the red line which is the actual performance was above the target rate. But soon after that it widened and interestingly the short form, for example, the real GDP was $26 \%$ behind the target and the per capital GDP was $50 \%$ behind the target.

But this was the actual performance and we needed to do a wakeup call and I am very happy to see this today especially under the leadership of YAB Perdana Menteri, this message is firmly out that we are at the critical junction, either we do it or will we be left behind. 
This is the message which is out today. Throughout Malaysia, in all compartments of the economy, that we need to change. If not this gap will widen even further and we have only 10 years basically to close this gap.

Now if we look at the growth momentum, this is how it is. Basically the growth momentum has declined, I mean growing to are higher upper-middle income economy. To probably achieve $10 \%$, or $7 \%$ is very difficult, but the target now is to reach about $6 \%$ growth. There is only one economy that is large. Surprisingly, it is not far from us. China, for example, has been able to sustain its growth at 10 to $11 \%$. This is a huge path. We need to regain the momentum but structurally, I mean, many of us are very familiar with this. Basically we talk about shifting to knowledge economy and so on. That is where we are. So, this plan needs to move to the right side. If we want to get our structure to fit with the kind of activities that we are doing, we have to move the readiness of Malaysian economy, to be a knowledge-intensive, innovation-based economy. But to do that, the most important aspects are to have talents.

In Malaysia today, if we look at the workforce of certain sectors, who are we attracting. Is Malaysia attractive to attract, so called knowledge-high sophistication workers? Over the years we see an influx of unskilled foreign workers. The concern is that it is not about issues to reject them. I used to say something like that but I think I have changed my mind after being abroad for years. The problem is that they are coming in at the state of economic development which is already advanced. It does not hold a country from moving forward. But in Malaysia we are in the state of shifting towards a high-income economy. If we are not careful enough about dealing with this influx of unskilled work-force, the issue is, I'm not going to give the answer, but the concern is whether it works basically for Malaysia to move forward. A week ago, the YAB Perdana Menteri announced about achieving international standards. Can you have this standard if the workforce is coming at a different standard. If you went to a pasar borong for example, you can see the standard of how we handle fish, vegetables and so on and so forth. The way we transport vegetables, is just like the way we transport the other things. This is not the standard. This is not acceptable for a higher-income economy. So, there are many other things that we have to adapt. If you look at the chart down there, Malaysia is not that small. Malaysia has a globalized economy, Malaysia is wide some what like 'chili'. Singapore has a very small global economy. But Malaysia is open. Malaysia actually should not be opened. 
I remember that when we were involved in the FTA negotiation we looked at the tariff. Our tariff was quite low. But the problem is, how much do you gain from globalization. The tariff is more about trade barriers. But the gain from globalization actually requires the other two gates to be opened. This is the concept in the APEC platform where I had a couple of meetings. There is an initiative called LAISR (Leader Agenda to Implement Structure Reform). And the focus of the agenda is about behind the border. Nobody talks about what is at the border anymore. Behind the border means rules, guidelines, and policies, after you enter the country. You can enter Malaysia, but you cannot open your branch in KL. You can enter Malaysia, but you have to open your factory somewhere else in Sarawak, for example. Now, these are the things, and also the case of doing business. Yes, I'm there but, how do I get through to make sure my business is effective. So the other two gates have to be our focus. The $10^{\text {th }}$ Malaysia Plan must address this element. We should not be talking about the first gate anymore. We should not be talking about achieving a zero poverty figure. In economics when you talk about inflation, 3\% for unemployment, for example, is considered 0 . So there's no such thing as $0 \%$ unemployment. So achieving $3 \%$ is probably good. Think more about improving the quality of life, about shifting the middle class income. Those are the issues. Some of the issues that we addressed in the 1970's are already outdated. Let's not carry those issues anymore. Shift those issues. There are various other concerns with respect to those issues.

Look at the chart. There are 2 lines. The first 2 lines are in a parallel pattern. It means that the pattern of growth in GNP per capital income is actually a reflector of the upper-middle income group. When we look at the lower income group, you see that the slope is a bit lower. This is the concept, because if you have $40 \%$ of your household at low income, the issues of shifting towards advanced economy will be more challenging. But if $40 \%$ of the nation still requires that, than how do we deal with it. The idea is actually to shift the economy to the day economy. We used to be a resourced-based economy, productionbased economy and now we want to move to knowledge intensive and so on. Now the concern is, is this economy transformation in everybody's mind in the country. In the new economic model this is the view of the vision of what 2020 is all about. So this is the end game basically. If we are able to put in place all those things that we heard just now, by 2020, these are the five major features of the Malaysian economy. 


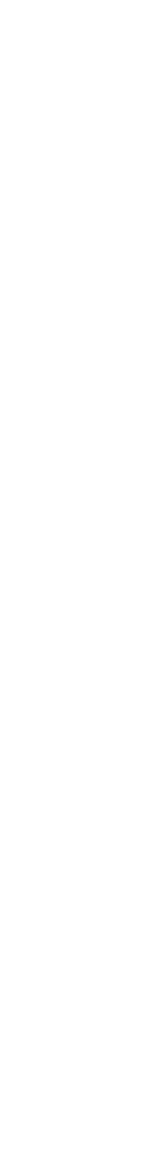

